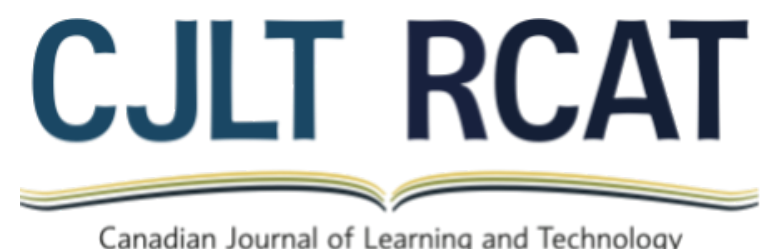

La Revue canadienne de l'apprentissage et de la technologie

Volume $47(1)$

Winter / Hiver 2021

\title{
Teachers Perceptions of Google Classroom: Revealing Urgency for Teacher Professional Learning
}

Perceptions des enseignants sur Google Classroom : révéler l'urgence de l'apprentissage professionnel des enseignants

Brandy A. Martin, University of Calgary

\begin{abstract}
As the use of educational technology is at the forefront of today's educational revolution, it is imperative that educators are employing online learning environments such as Google Classroom to enhance $21^{\text {st }}$ century pedagogy and student learning. This mixed method research study consisted of an online survey and interviews from K-12 educators in a small rural school district. The researcher concludes that using Google Classroom as an LMS will assist educators in creating learning environments that boast organization, accessibility, mobility, and $21^{\text {st }}$ century learning skills such as effective communication, critical thinking, collaboration, problem solving, creativity, and technology use. This research reveals continuing gaps between the possibilities of eLearning and the training of teachers to use it and develop their teaching practices within a technological mainstream that moves beyond positivity about its value. The researcher recommends that teachers receive immediate and sustained professional learning regarding the use of Google Classroom. This learning should focus on the pedagogical side of technology integration to enhance $21^{\text {st }}$ century learning.
\end{abstract}

Keywords: $21^{\text {st }}$ century learning; eLearning learning; educational technology; google classroom; mobile learning; professional learning

\section{Résumé}

L'utilisation des technologies éducatives étant au premier plan de la révolution éducative actuelle, il est impératif que les éducateurs utilisent des environnements d'apprentissage en ligne tels que Google Classroom pour améliorer la pédagogie du 21e siècle et l'apprentissage des étudiants. Cette étude de recherche à méthode mixte a consisté en une enquête en ligne et des entretiens avec des éducateurs de la maternelle à la $12^{\mathrm{e}}$ année dans un petit district scolaire rural. Le chercheur conclut que 
l'utilisation de Google Classroom comme plateforme d'apprentissage en ligne aidera les éducateurs à créer des environnements d'apprentissage qui se caractérisent par l'organisation, l'accessibilité, la mobilité et les compétences d'apprentissage du $21^{\mathrm{e}}$ siècle telles que la communication efficace, la pensée critique, la collaboration, la résolution de problèmes, la créativité et l'utilisation de la technologie. Cette recherche révèle des écarts persistants entre les possibilités de l'apprentissage en ligne et la formation des enseignants pour l'utiliser et développer leurs pratiques pédagogiques au sein d'un courant technologique qui va au-delà de la positivité sur sa valeur. Le chercheur recommande que les enseignants reçoivent un apprentissage professionnel immédiat et soutenu concernant l'utilisation de Google Classroom. Cet apprentissage devrait se concentrer sur l'aspect pédagogique de l'intégration de la technologie pour améliorer l'apprentissage du $21^{\mathrm{e}}$ siècle.

Mots clés : Apprentissage du 21e siècle ; apprentissage en ligne ; technologie éducative ; Google Classroom ; apprentissage mobile ; apprentissage professionnel

\section{Introduction}

Educators must be given professional learning opportunities regarding eLearning to meet the needs of today's learners and educational technology demands. Students need to be proficient in $21^{\text {st }}$ century skills such as effective communication, critical thinking, collaboration, creativity, problem solving, and technology use upon leaving the K-12 school system (Bellanca \& Brand, 2010; Saavedra \& Opfer, 2012; Scott, 2015). Bellanca and Brand (2010) argue that schools are not preparing students for the "economic workforce, citizenship opportunities, and demands of the $21^{\text {st }}$ century" (p. 2). Educators must respond by changing the dynamics of the K-12 classroom to improve teaching and learning using educational technologies (Chew et al., 2018). The traditional modes and models of education are shifting with the use of educational technology and eLearning (Abazi-Bexheti et al., 2018). Ertmer et al. (2012) explains that educators must consider the needs of today's students, as they are different from those of previous generations.

This mixed methods study focused on teachers' perceptions of Google Classroom as an effective online learning environment and what they see as the advantages and challenges of using Google Classroom. This study included an inquiry into the strategies and barriers to implementation, and how teachers can implement Google Classroom to transform teaching and learning. As minimal research exists on the use of Google Classroom, this study concludes that Google Classroom is effective for $21^{\text {st }}$ century teaching and learning and reveals a gap between the promise of using educational technology and its actual use in the classroom. Abazi-Bexheti et al. (2018) contend that further study is needed to determine how to support teachers' use of learning management systems and how to integrate them most effectively into the education context. The researcher recommends that teachers receive immediate and sustained professional learning to effectively use Google Classroom; this learning should focus on using technology to enhance pedagogy. 


\section{Statement of Research}

This study explored K-12 educators' perceptions regarding advantages and disadvantages of using Google Classroom in a small rural school district in Alberta, Canada during the 2018-2019 school year. The researcher investigated educators' perceived benefits and drawbacks of using Google Classroom, overall effectiveness of Google Classroom as an online learning environment, and strategies and barriers of implementing Google Classroom.

\section{Literature Review}

\section{eLearning and Learning Management Systems}

Traditional modes of education are shifting towards new approaches in teaching and learning with the application of eLearning tools that include learning management systems (Abazi-Bexheti et al., 2018; Tantri \& Efendi, 2020). Abazi-Bexheti et al. (2018), Lonn and Teasely (2009), and Tantri and Efendi (2020) explain that learning management systems (LMS) are web-based technologies that provide teachers and students with opportunities to share materials, submit assignments, and collaborate online. LMS are a tool for course management where course content and assignments are housed and online learning activities occur (Abazi-Bexheti et al., 2018). Ekuase-Anwansedo et al. (2018) explain that the "goal of every LMS implementation is to ensure the use of the system by instructors and students to enhance teaching and communication thereby enhancing learning outcomes of the students" (p. 165).

Abrami et al. (2006) state that eLearning is a general term that includes the application of computer and online technology to education. To further this definition, the Canadian Council on Learning (CCL) defines eLearning as "the development of knowledge and skills through the use of information and communication technologies (ICTs) particularly to support interactions for learninginteractions with content, with learning activities and tools, and with other people" (Abrami et al., 2006, para. 12). Google Classroom is an online tool for education and supports multiple interactions in an online learning environment.

\section{eLearning to Enhance Student Learning}

The use of eLearning tools creates a learning environment that is highly connected, accessible, and responsive to student's needs. Lonn and Teasley (2009) contend that LMS provide tools for learning that are preferred by today's generation of tech savvy students. As our world becomes more connected and mobile, so should our learning environments. Teachers and students can access course content, assignments, work, and communicate from any device with LMS (Abrami et al., 2006; Ventayen et al., 2018). Increased mobility and accessibility also lead to increased student motivation and increased responsiveness to student needs via immediate feedback capabilities (Abid Azhar \& Iqbal, 2018; Abrami et al., 2008). 
The use of LMS is enhancing student learning opportunities and engaging them in the creation of knowledge. Abrami et al. (2008) and Tantri and Efendi (2020) assert that LMS create learning experiences that are more situated, active, learner-centered, collaborative, and interconnected when compared to traditional teaching methods. Lonn and Teasley (2009) contend that LMS are "consistent with constructivist approaches to learning rather than simple transmission of knowledge models" (p.686). For educators and students to reap the benefits of eLearning and LMS it is important to recognize the learning opportunities they offer, and to use LMS in a manner that transforms teaching and learning (Harrell, 2017; Lonn \& Teasley, 2009; Scott, 2015).

\section{Considerations of eLearning}

While there are many advantages to eLearning, there are also counterpoints to consider. Abrami et al. (2008) bring forth claims to limitations of eLearning including technology dependency, learner isolation, and an imbalance of computer skills over academic skills. Another important consideration is the digital divide (Selwyn, 2004). Selwyn (2004) explains that the digital divide is a "dichotomous divide between those citizens who are 'connected' and those citizens who remain 'disconnected' from technology and information" (p. 334). This divide can have global implications in comparing countries, but also local implications in comparing individual students within an educational setting. When implementing eLearning it is important to ensure we are not creating a situation of digital have and have-nots (Selwyn, 2004). These claims are generalized and require further research.

\section{Supporting eLearning}

Teachers would benefit from professional learning relating to instructional design practices for the use of educational technologies (Abrami et al., 2008). General models of eLearning exist such as the 5 Stage Model (Salmon, 2011) and the SAMR model (Puentedura, 2013); however, more specific learning models are necessary for teachers to successfully implement eLearning into their classrooms. Mishra and Koehler's (2006) Technological Pedagogical and Content Knowledge framework, for example, provides guidance on how to integrate technology into teaching practices. According to this framework, effective use of educational technology requires planning, implementation, assessment, and problem-solving of eLearning practices on a continual basis.

Ventayen et al. (2018) state that "there are really no specific models for eLearning, only enhancements of existing models of learning which use technology to achieve better learning outcomes" (p.47). Given that eLearning is a new area, it is likely that best practices will undergo refinement and enhancement as technologies are studied and used in education. The emphasis of eLearning models needs to be on the pedagogical application of technology.

Effective professional development is crucial for the successful implementation of eLearning practices in classrooms. Jacobsen et al. (2002) contend that professional development regarding the use of technology in the classroom needs to be just in time, collaborative, situated in authentic tasks, supportive of inquiry and risk-taking, and reflective. Abrami et al. (2008) mirror these ideas, stating that prompt, in-depth, and ongoing support should be offered to teachers to maximize the effectiveness of educational technologies. 


\section{Barriers to eLearning in the Classroom}

Addressing barriers to educational technology and eLearning implementation requires identification and discussion. Ertmer $(1999,2012)$ identifies first and second order barriers to change and proposes strategies for effective technology integration. First order barriers have to do with lack of external resources (technology, software, training), while second order barriers surround teacher beliefs and confidence in technology integration. Abid Azhar and Iqbal (2018) also identify a lack of teacher training and technology readiness as barriers to teachers implementing educational technology such as Google Classroom. These considerations support the claim that teachers require immediate and ongoing professional learning regarding effective eLearning practices. Ertmer et al. (2012) state that due to the recent increase in access to technology, many of the first order barriers have disappeared.

The most significant barrier to eLearning lies in teachers' pedagogical beliefs and perceptions about the integration of technology. To extend this idea, Jacobsen et al. (2002) identify a lack of teacher confidence in using technology as a barrier to classroom integration. Ertmer et al. (2012) identify teacher professional development as the number one barrier to technology adoption in the classroom.

\section{Advantages of Using Google Classroom}

Google Classroom is an online tool wherein educators can create classes, manage assignments, give quizzes, provide feedback, and supplement class materials, all in one online space (Google for Education, n.d.). The use of Google Classroom can improve organization of classes, course materials, and assignments (Abid Azhar \& Iqbal, 2018; Martínez-Monés et al., 2017; Shaharanee et al., 2016; Ventayen et al., 2018). Providing immediate feedback, enhancing communication, tracking student progress and performance, and assessment using Google Classroom will also increase productivity (Davidson \& Chong, 2017; Nevin, 2009; Shaharanee et al., 2016; Ventayen et al, 2018).

Using Google Classroom allows students the opportunity to engage in $21^{\text {st }}$ century learning (Harrell, 2017; Nevin, 2009; Shaharanee et al., 2016; Ventayen et al, 2018). Students can build on skills such as collaboration, problem solving, creativity, and critical thinking, and become comfortable using technology for academic purposes (Saavedra \& Opfer, 2012; Scott, 2015). Shaharanee et al. (2016) contend that Google Classroom can shift the focus of the classroom "from one that is teacher-centered to one that is learner-centered and open to inquiry, dialogue, and creative thinking on the part of learners as active participants" (para. 7). In these ways, the use of Google Classroom can be transformative to students' $21^{\text {st }}$ century learning experiences.

The benefits of using Google Classroom can extend to include the school. Google Classroom is commonly chosen as an LMS because it is free (Dessoff, 2010). Harrell (2017) contends that the "implementation of Google Classroom can lead to a positive shift in school community and climate in regard to the use of educational technology" (p. 32). The advantages of using Google Classroom move past organizing, producing, and enhancing $21^{\text {st }}$ century learning to creating a culture of school technology use. 


\section{Considerations of Using Google Classroom}

Educators must consider whether Google Classroom is an appropriate tool for use in their specific classroom contexts. Davidson and Chong (2017) explain that one of the biggest drawbacks of Google Classroom is the lack of a "centralized offline facility/platform/app whereby a variety of document types can be worked on and managed simultaneously" (pg. 8). To access their schoolwork outside of the classroom, students need access to technology and the Internet. Educators must consider if this presents a barrier to the use of Google Classroom for students in their context. This point is critical in combating the digital divide described by Selwyn (2004). Additionally, Abid Azhar and Iqbal (2018) explain that students new to using Google Classroom may face a steep learning curve. Educators may need to spend time coaching students on how to use this tool. Martínez-Monés et al. (2017) state that Google Classroom has limited tools when it comes to automatically managing lists of students, gradebooks, and student progress in assignments, and question the validity of Google Classroom as an LMS due to this limitation. Recently, Google has made changes to Google Classroom, such as adding a gradebook, to increase functionality. The possible drawbacks of using Google Classroom have not been studied extensively.

\section{Methods}

This study used a mixed methods research approach. Quantitative design employed a survey of educators' views, attitudes, and opinions about Google Classroom. The survey was created in Google Forms and sent out via district email. The survey included 7 closed items and 10 open items (Table 1) which were created by the researcher. The closed items questions were formatted as multiple choice, check boxes, or drop-down menu items. The open-ended questions were formatted as short answer written responses. The data collected through this survey was coded into common themes which will be presented in the results section of this article. Data was collected from 11 participants from a small rural school district of approximately 200 teachers and 4000 students in Alberta, Canada. The participants represent educators from the K-12 school system. Teachers who do not use Google Classroom did not participate in this study, although they were invited.

Qualitative design consisted of four interviews with a subset of participants from the surveyed cohort. Interview participants were chosen based on their K-12 divisional representation: K-6 (N=2), 7-9 $(\mathrm{N}=1)$, and 10-12 ( $\mathrm{N}=1)$. The interviews were completed in a face-to-face informal setting and consisted of 11 open-ended questions. The questions asked mimicked those presented in Table 1. The interview questions were used to clarify information given in the survey and obtain important details regarding survey items. The interviews provided a deeper understanding of educators' perspectives of Google Classroom (Wood et al., 2005). 


\section{Table 1}

Online Survey Questions: Teachers’ Perceptions of Google Classroom

\begin{tabular}{ll}
\hline Question & Question Type \\
\hline What grade level do you teach? & Closed \\
How would you describe your use of Google Classroom in your teaching practice? & Open \\
What tools do you use in Google Classroom? & Closed \\
$\begin{array}{l}\text { Are there any other tools that you use in Google Classroom that were not mentioned } \\
\text { above? }\end{array}$ & Open \\
$\begin{array}{l}\text { What tools/resources helped you to implement Google Classroom into } \\
\text { your teaching practice? }\end{array}$ & Open \\
$\begin{array}{l}\text { What benefits do you see in using Google Classroom for teachers? } \\
\text { What benefits do you see in using Google Classroom for students? }\end{array}$ & Open \\
$\begin{array}{l}\text { What drawbacks do you see in using Google Classroom for teachers? } \\
\text { What drawbacks do you see in using Google Classroom for students? }\end{array}$ & Open \\
$\begin{array}{l}\text { What barriers do you think exist in preventing teachers from using Google Classroom? } \\
\text { Please add any other barriers you perceive to teacher implementing the } \\
\text { use of Google Classroom. You may also wish to explain one or more of } \\
\text { your above choices. } \\
\begin{array}{l}\text { Overall, would you consider Google Classroom to be an effective online } \\
\text { learning environment for students and teachers? }\end{array}\end{array}$ & Closed \\
Closed
\end{tabular}

\section{Data Analysis}

The researcher coded survey and interview data into emerging themes using inductive coding. Survey data was analyzed using descriptive statistics. Connections were made between survey responses and interview responses to formulate themes. The themes were then summarized and categorized by each research question. Connections were made between the themes present in the data and themes present in the literature. Lastly, discrepancies between the literature and the data were identified.

Interpretation of the survey and interview data focused on common experiences and perspectives among the participants A deep description of the research setting and participants is provided to enhance transferability of this study to various educational contexts, per Korstjens and Moser (2018). Data from 
the survey and interviews are generalized to similarly enhance transferability, per Creswell (2014) and Korstjens and Moser (2018).

\section{Results}

\section{Which Tools are Employed Most in Google Classroom?}

This study reveals that the most used tools in Google Classroom are Google Docs and Google Slides (Figure 1). This supports the idea that teachers are using this technology for substitution of traditional teaching methods. Puentedura (2013) explains that to transform student learning, educators should be focusing on modifying and redefining learning tasks using technology. Educators should be modifying their use of Google Classroom with learning goals that enhance and transform student learning, not simply using it for substitution of traditional learning tasks (Koehler, 2012).

\section{Figure 1}

What Tools do Teachers Use in Google Classroom? $(N=11)$

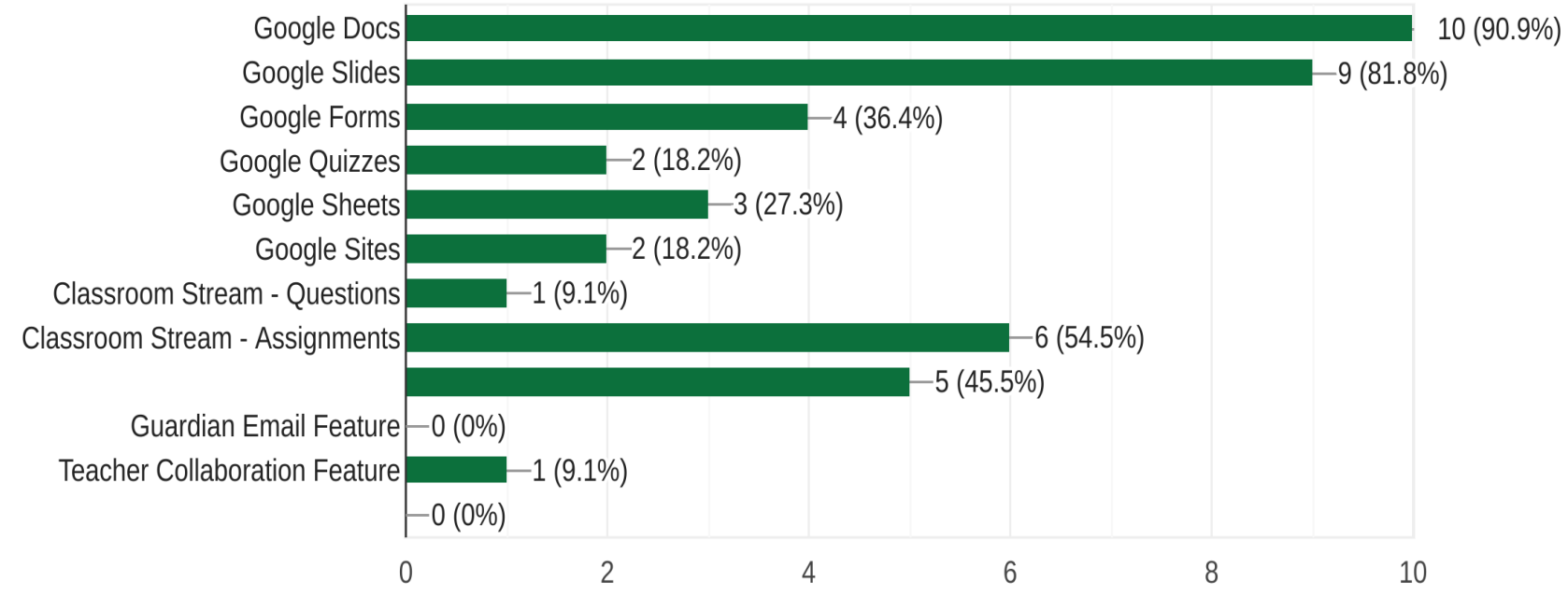

One interview participant said they use embedded features of Google Classroom such as voice to text and readability tools for students with specialized learning needs. A second interview respondent gave an example of using Google Draw and Google Translate to assist English language learners. It is important to note the use of Google Classroom for personalization of learning as a benefit (Abid Azhar \& Iqbal, 2018).

\section{What Tools did Teachers Use to Implement Google Classroom?}

Seven of 11 survey participants claimed that access to personnel, such as educational technologists, and access to professional development opportunities are most effective in assisting teachers in implementing Google Classroom. Chew et al. (2018) explain that personnel should be on site 
and situated within the teaching context to fully understand teacher, student, and technology needs. Interview respondents also noted the need for guidance and ongoing professional learning for using Google Classroom. Abrami et al. (2008) confirms this idea, stating that "immediate, extensive, and sustained support should be offered to teachers in order to make the best out of eLearning" (para. 9).

Self-teaching was another predominant strategy identified for implementing Google Classroom. Chew et al. (2018) explain that "when a technology is introduced into schools, the burden of learning and using the technology usually lies on the teachers" (para. 30). Interview respondents stated that they use resources such as YouTube, district tutorial videos, experimentation, and student and teacher collaboration to learn how to use Google Classroom. If the integration of educational technology falls on the shoulders of the teacher as Chew et al. (2018) suggests, then this learning process can be exhausting. Fullan (2011) presents the idea of innovation fatigue, which is caused by a constant stream of new ideas and practices. One participant stated that "for teachers unfamiliar with it (Google Classroom) the program might seem daunting to learn." Innovation fatigue was a reported barrier to implementing Google Classroom.

\section{What are the Benefits of Using Google Classroom for Teachers and Students?}

The most significant benefits observed for teachers and students include enhanced organization, accessibility, and mobility (Abid Azhar \& Iqbal, 2018; Espinosa et al., 2017; Martínez-Monés et al., 2017; Shaharanee et al., 2016). Features of Google Classroom that assist in more effective timely communication, such as collaboration, immediate feedback, tracking student progress, and assessment measures, were also benefits for educators (Abid Azhar \& Iqbal, 2018; Shaharanee et al., 2016). One survey respondent stated that "Students can have a more collaborative learning experience and can use multiple resources for learning" through using Google Classroom.

An interview respondent claimed that the use of Google Classroom prepares students for their future through the technological skills they learn. The respondent stated that in today's workforce you need to be able to use technology; jobs do not require you to sit down and complete worksheets. Harrell (2017) and Shaharanee et al. (2016) share the idea that the use of Google Classroom enhances $21^{\text {st }}$ century skills, which include, but are not limited to, effective communication, critical thinking, collaboration, problem solving, innovation, creativity, and technological use (Scott, 2015; Tantri \& Efendi, 2020). Students must employ these skills to gain deep learning and understanding (Tantri \& Efendi, 2020). Tantri and Efendi (2020) contend that the use of "technology nowadays is able to assist the students to achieve personalized, collaborative, and informal learning" (p. 24). Chew et al. (2018) explain that as learners use different learning environments, such as technology, they can transfer these skills into their work environments in the future. Using Google Classroom can help teachers support this type of deep and connected learning.

\section{What are the Drawbacks of Using Google Classrooms for Teachers and Students?}

Six of 10 survey respondents noted that learning time for teachers is a drawback to using Google Classroom. Teachers in this study who learned to use Google Classroom through self-teaching noted that professional support is still required to integrate effective pedagogical practices and Google 
Classroom features to create meaningful learning opportunities (Chew et al., 2018). This indicates the need for professional learning in this area.

Student access to technology at home was identified as a drawback to using Google Classroom. Three interview respondents explained that this is a specific issue in this teaching district because the community is a generally lower socio-economic demographic. One interview respondent explained if a student could not access Google Classroom at home, then they would be at a disadvantage. Davidson and Chong (2017) contend the lack of offline usability of Google Classroom is a drawback to its use. Educators must consider the appropriateness of using Google Classroom in their teaching contexts.

Lastly, a category of drawbacks to using Google Classroom emerged regarding the use of technology enabled learning environments. Both survey and interview data showed that distractibility caused by access to the Internet impedes proper use of Google Classroom by students. An interview respondent noted a concern for students being immersed in online learning environments in school, as they spend much of their free time online. Concerns about plagiarism were identified. Respondents also noted concern with the amount of information being stored online using Google Classroom.

\section{What Barriers are Present in Implementing Google Classroom?}

The most frequent barrier to the implementation of Google Classroom perceived was educators' lack of technology confidence and readiness (Table 2) (Abid Azhar \& Iqbal, 2018; Ertmer et al., 2012; Jacobsen et al., 2002). Lack of equipment and networking were also identified as a second significant barrier. An interview respondent explained that if teachers and students do not have access to 1:1 technology, taking the time to learn and implement Google Classroom may not be viable. A third barrier identified was teacher burnout in trying new technologies. A fourth barrier identified in this study was the lack of time to learn Google Classroom. Educators need to consider how they can use technology in the classroom, such as mobile devices, to tackle barriers to educational technology integration. Ertmer et al. (2012) explain that as education moves forward, we are getting closer and closer to having 1:1 technology in the classroom. One example of this is the increased use of mobile learning in the classroom (Squire \& Dikkers, 2012). This shift in education may help to combat the barriers to using Google Classroom this study identifies.

\section{Table 2}

What Barriers do You Think Prevent Teachers from Using Google Classroom? (N=11)

\begin{tabular}{llll}
\hline Barrier & $N$ & $\%$ \\
\hline Lack of teacher confidence in implementing new technology & 9 & 82 \\
Lack of equipment and network needs & 8 & 72 & 64 \\
Teacher burnout in trying new technologies & 7 & 6 & 55 \\
Lack of time to learn how to use Google Classroom & 5 & 45 \\
Lack of professional development opportunities & 1 & 9 \\
Lack of connection to teacher needs & & 1 \\
\hline
\end{tabular}




\section{Overall, is Google Classroom an Effective Online Learning Environment?}

Overall, survey and interview respondents perceived Google Classroom to be an effective online learning environment. One interview respondent explained that Google Classroom is effective because it engages students, enables immediate feedback, and fosters digital citizenship. A second respondent explained that Google Classroom creates connections between the home and school and provides students with opportunities to work with technology. A third respondent felt that Google Classroom was effective because it increases accessibility for teachers and students. Lastly, a fourth respondent claimed that Google Classroom was an effective online learning tool because it is user friendly, accessible, and enhances organization.

\section{Discussion}

This study reveals that although teachers perceive Google Classroom to be an effective online learning environment, they are not using it to its fullest potential. In general, for educational technology implementation to be effective, more focus on preservice teacher education is needed. Chew et al. (2018) and Jacobsen et al. (2002) state that there is a need for preservice teachers to experience effective use of education technologies in university and in their teaching practicums. This will ensure that when educators enter the classroom, they will be ready and confident in using educational technologies such as Google Classroom. This type of preservice education would assist in addressing barriers to implementing LMS identified in this study, such as teacher confidence.

A second important factor is teacher professional development opportunities. Chew et al. (2018) explain that currently, teachers are expected to use technology in their classrooms, without having the proper training or experience in doing so. Immediate and sustained professional development for educators is key to effectively using educational technologies such as Google Classroom to enhance student learning (Chew et al., 2018; Jacobsen et al., 2002; Squire, 2010). Abrami et al. (2008) state that for teachers to optimize learning, the focus of professional development must be more on the pedagogical side of $21^{\text {st }}$ century teaching as opposed to technical skills. Educational technologists are an important resource for professional learning. Chew et al. (2018) explain that unless we change how we teach and how students interact with content, technology integration will not make a difference to student learning.

\section{Implications for Future Study}

There are questions and gaps in the literature regarding the use of Google Classroom. The gap between teachers' perceptions of Google Classroom and actual use is problematic. This study uncovered the question: If teachers feel as though Google Classroom in an effective online learning environment, then why is it not being used to its fullest potential? Also, research on Google Classroom should shift from being teacher-centered to student-centered. Abrami et al. (2008) explain that student use of technology is more important than teacher use of technology in the classroom. Ertmer (2012) contends that the most important issue surrounding educational technology is how our students are tapping into its potential. Lastly, there is a need for research on the parent role and participation in the use of Google 
Classroom. Parents can interact with their children in unprecedented ways using Google Classroom; however, this potential has been largely untapped. Consideration should be given to these questions for future research.

\section{Limitations}

Due to the small sample size, the results of this study cannot be generalized to larger populations. Only 11 out of a possible 200 teachers completed the survey, and only 4 of the 11 survey respondents were interviewed. Non-users of Google Classroom did not participate although they were invited to do so. This may bring bias to the research as only those who are comfortable using Google Classroom participated. Lastly, all the data from the literature review and this study is from 2014 or later, as Google Classroom had only been available for five years when this study began. Hence, generalizations about the long-term effects of using Google Classroom cannot be made.

\section{Conclusion}

This study contributes to research on the effectiveness of LMS and eLearning tools to enhance $21^{\text {st }}$ century learning. This study shows that teachers perceive Google Classroom to be an effective online learning environment. This study also reveals that there continues to be gaps between the possibilities of eLearning and actual use in K-12 classrooms. Professional learning of Google Classroom needs to focus on matching sound pedagogy with the use of technology to engage students in $21^{\text {st }}$ century learning experiences. It is imperative that educators are responsive to educational technology as it is an "ever-changing process which aligns with the changing needs of learners and teachers in the classroom, along with the emergence of new and improved technology" (Chew et al., 2018, para. 45). Further research should examine best practices in professional learning that will effectively support K12 educators in implementing and effectively using LMS such as Google Classroom. 


\section{References}

Abazi-Bexheti, L., Kadriu, A., Apostolova-Trpkovska, M., Jajaga, E., \& Abazi-Alili, H. (2018). LMS solution: Evidence of Google Classroom usage in higher education. Business Systems Research, 9(1), 31-43. https://doi.org/10.2478/bsrj-2018-0003

Abid Azhar, K., \& Iqbal, N. (2018). Effectiveness of Google Classroom: Teachers' perceptions. Prizren Social Science Journal, 2(2), 52-66.

https://dataverse.harvard.edu/dataset.xhtml?persistentId=doi:10.7910/DVN/FJVYI4

Abrami, P., Bernard, R., Wade, A., Schmid, R., Borokhovski, E., Tamin, R., Surkes, M., Lowerison, G., Zhang, D., Nicolaidou, I., Newman, S., Wozney, L., Peretiatkowicz, A., \& Peretiatkowicz, A. (2006). A review of e-learning in Canada: A rough sketch of the evidence, gaps and promising directions. Canadian Journal of Learning and Technology / La revue canadienne de l'apprentissage et de la technologie, 32(3). https://doi.org/10.21432/t2qs3k

Alberta Education (2013). Learning and technology policy framework.

https:/education.alberta.ca/media/1046/learning-and-technology-policy-framework-web.pdf

Bellanca, J., \& Brandt, R. (2010). $21^{\text {st }}$ century skills: Rethinking how students learn. Solution Tree.

Chew, S., Cheng, W., Kinshuk, I., \& Chen, N. (2018). Exploring challenges faced by different stakeholders while implementing educational technology in classrooms through expert interviews. Journal of Computers in Education, 5(2), 175-197. https://doi.org/10.1007/s40692018-0102-4

Creswell, J. W. (2014). Research design: Qualitative, quantitative, and mixed methods approaches (4th ed.). SAGE Publications, Inc.

Davidson, P., \& Chong, Y. T. (2017, May 19). MS Classroom, Google Classroom \& allied apps: Comparison from an educational perspective. https://www.researchgate.net/publication/317590573_MS_Classroom_Google_Classroom_allied _apps_comparison_from_an_educational_perspective. doi:10.13140/RG.2.2.36414.08000

Dessoff, A. (2010). Google and Microsoft go to school. Education Digest, 76(4), 4-7. http://web.b.ebscohost.com.ezproxy.lib.ucalgary.ca/ehost/detail/detail?vid=0\&sid=9d7ada3902bd-4fd5-bf39-

e78091b2a563\%40sessionmgr101\&bdata=JnNpdGU9ZWhvc3QtbG12ZQ\%3d\%3d\#db=rch\&AN $=55455320$

Ekuase-Anwansedo, A., Craig, S.F., \& Noguera, J. (2018). How to survive a learning management system (LMS) implementation? Proceedings of the 2018 ACM SIGUCCS annual conference. ACM Digital Library. https://doi.org/10.1145/3235715.3235735 
Ertmer, P. (1999). Addressing first- and second-order barriers to change: Strategies for technology integration. Educational Technology Research and Development, 47(4), 47-61. https://doi.org/10.1007/bf02299597

Ertmer, P., Ottenbreit-Leftwich, A., Sadik, O., Sendurur, E., \& Sendurur, P. (2012). Teacher beliefs and technology integration practices: A critical relationship. Computers \& Education, 59(2), 423 435. https://doi.org/10.1016/j.compedu.2012.02.001

Espinosa, N., Estira, K. L., \& Ventayen, R. J. M. (2017). Usability evaluation of google classroom: Basis for the adaptation of GSuite e-learning platform. Asia Pacific Journal of Education, Arts, and Science, 5(1), 47-51. http://apjeas.apjmr.com/wp-content/uploads/2017/12/APJEAS2018.5.1.05.pdf

Fullan, M. (2011). Change leader: Learning to do what matters most (1st ed.). John Wiley \& Sons.

Government of Canada (2017). The TCPS 2 tutorial course on research ethics (CORE). Panel on Research Ethics. https://ethics.gc.ca/eng/education_tutorial-didacticiel.html

Harrell, D. (2017). Beyond surfing. Education Digest, 82(7), 32-35. http://ezproxy.lib.ucalgary.ca/login?url=http://search.ebscohost.com/login.aspx?direct=true $\& \mathrm{db}=$ ehh\&AN=121177460\&site=ehost-live

Jacobsen, M., Clifford, P., \& Friesen, S. (2002). Preparing teachers for technology integration: Creating a culture of inquiry in the context of use. Contemporary Issues in Technology and Teacher Education [Online serial], 2(3), 363-388. https://www.citejournal.org/volume-2/issue-302/current-practice/preparing-teachers-for-technology-integration-creating-a-culture-of-inquiryin-the-context-of-use

Koehler, M. (2012). TPACK explained. https://matt-koehler.com/tpack2/

Korstjens, I., \& Moser, A. (2018). Series: Practical guidance to qualitative research. Part 4: Trustworthiness and publishing. European Journal of General Practice, 24(1), 120-124. https://doi.org/10.1080/13814788.2017.1375092

Lonn, S., \& Teasley, S. D. (2009). Saving time or innovating practice: Investigating perceptions and uses of Learning Management Systems. Computers \& Education, 53(3), 686-694. https://doi.org/10.1016/j.compedu.2009.04.008

Martínez -Monés, A., Reffay, C., Torío, J. H., \& Cristóbal, J. A. M. (2017). Learning analytics with Google Classroom. Proceedings of the $5^{\text {th }}$ International Conference on Technological Ecosystems for Enhancing Multiculturality. ACM Digital Library. https://doi.org/10.1145/3144826.3145397

Mishra, P., \& Koehler, M. J. (2006). Technological pedagogical content knowledge: A framework for integrating technology in teachers' knowledge. Teachers College Record, 108(6), 1017-1054. http://one2oneheights.pbworks.com/f/MISHRA_PUNYA.pdf 
Nevin, R. (2009). Supporting $21^{\text {st }}$ century learning through google apps. Teacher Librarian, 37(2), 3538. http://web.b.ebscohost.com.ezproxy.lib.ucalgary.ca/ehost/detail/detail?vid=1\&sid=9ead3af6$2243-4 \mathrm{e} 6 \mathrm{e}-\mathrm{b} 72 \mathrm{c}-$

0ffc3bfbd5c1\%40sessionmgr101\&bdata=JnNpdGU9ZWhvc3QtbG12ZQ\%3d\%3d\#AN=4750019 $0 \& \mathrm{db}=\mathrm{rch}$

Puentedura, R. R. (2013, May 29). SAMR: Moving from enhancement to transformation. http://www.hippasus.com/rrpweblog/archives/000095.html

Saavedra, A., \& Opfer, V. (2012). Learning 21 st-century skills requires 21 st-century teaching. Phi Delta Kappan Magazine, 94(2), 8-13. https://doi.org/10.1177/003172171209400203

Salmon, G. (2011). E-moderating: the key to online teaching and learning. Routledge.

Scott, C. L. (2015). The futures of learning 3: What kind of pedagogies for the 21st Century? UNESCO. http://repositorio.minedu.gob.pe/handle/20.500.12799/3747Selwyn, N. (2004). Reconsidering political and popular understandings of the digital divide. New Media \& Society, 6(3), 341-362. https://doi.org/10.1177/1461444804042519

Shaharanee, I. N M., Jamil, J. M., \& Rodzi, S. S. M. (2016). Google Classroom as a tool for active learning. https://doi.org/10.1063/1.4960909

Spark learning with Gsuite for education. (n.d.). Google for Education. https://edu.google.com/

Spector, J. M. (2012). Foundations of educational technology. Routledge.

Squire, K., \& Dikkers, S. (2012). Amplifications of learning. Convergence: International Journal of Research into New Media Technologies, 18(4), 445-464. https://doi.org/10.1177/1354856511429646

Tantri, N. R., \& Efendi, Y. (2020). Promoting e-learning platform to achieve $21^{\text {st }}$ century skills in teaching and learning process in school context. New Language Dimensions, 1(1), 22-28. https://journal.unesa.ac.id/index.php/nld/article/view/5007/4529

Ventayen, R. J. M., Estira, K. L. A., de Guzman, M. A., Cabaluna, C. M., \& Espinosa, N. N. (2018). Usability evaluation of Google Classroom: Basis for the adaptation of GSuite elearning platform. Asia Pacific Journal of Education, Arts, and Science, 5(1), 47-51. https://pdfs.semanticscholar.org/09ef/59bb37b619ef5850060948674cb495ddebb6.pdf?_ga=2.89 230296.216306900.1548042383-910885732.1548042383

Wood, E., Mueller, J., Willoughby, T., Specht, J., \& Deyoung, T. (2005). Teachers' perceptions: Barriers and supports to using technology in the classroom. Education, Communication \& Information, 5(2), 183-206. https://doi.org/10.1080/14636310500186214 


\section{Author}

Brandy A. Martin, University of Calgary Werklund School of Education. Since 2012, Brandy has been a K-12 educator. Upon finishing her Master of Education in 2019, she entered the field of educational technology. Currently, she is working as an educational technologist for a small rural school district in Alberta, Canada. The focus of her work is providing educators and students with the competencies necessary to use educational technologies for the benefit of learning and creating course content in STEM education. Email: brandy.martin1@ucalgary.ca

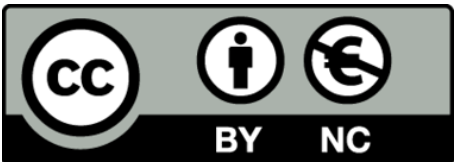

This work is licensed under a Creative Commons Attribution-NonCommercial CCBY-NC 4.0 International license. 